\title{
Front Matter: Volume 11467
}

, "Front Matter: Volume 11467," Proc. SPIE 11467, Nanoengineering:

Fabrication, Properties, Optics, Thin Films, and Devices XVII, 1146701 (4 September 2020); doi: 10.1117/12.2576442

SPIE. Event: SPIE Nanoscience + Engineering, 2020, Online Only 


\section{PROCEEDINGS OF SPIE}

\section{Nanoengineering: Fabrication, Properties, Optics, Thin Films, and Devices XVII}

Balaji Panchapakesan

André-Jean Attias

Wounjhang Park

Editors

24 August - 4 September 2020

Online Only, United States

Sponsored and Published by

SPIE 
The papers in this volume were part of the technical conference cited on the cover and title page. Papers were selected and subject to review by the editors and conference program committee. Some conference presentations may not be available for publication. Additional papers and presentation recordings may be available online in the SPIE Digital Library at SPIEDigitalLibrary.org.

The papers reflect the work and thoughts of the authors and are published herein as submitted. The publisher is not responsible for the validity of the information or for any outcomes resulting from reliance thereon.

Please use the following format to cite material from these proceedings:

Author(s), "Title of Paper," in Nanoengineering: Fabrication, Properties, Optics, Thin Films, and Devices XVII, edited by Balaji Panchapakesan, André-Jean Attias, Wounjhang Park, Proceedings of SPIE Vol. 11467 (SPIE, Bellingham, WA, 2020) Seven-digit Article CID Number.

ISSN: 0277-786X

ISSN: 1996-756X (electronic)

ISBN: 9781510637405

ISBN: 9781510637412 (electronic)

Published by

SPIE

P.O. Box 10, Bellingham, Washington 98227-0010 USA

Telephone +1 3606763290 (Pacific Time) · Fax +1 3606471445

SPIE.org

Copyright (c) 2020, Society of Photo-Optical Instrumentation Engineers.

Copying of material in this book for internal or personal use, or for the internal or personal use of specific clients, beyond the fair use provisions granted by the U.S. Copyright Law is authorized by SPIE subject to payment of copying fees. The Transactional Reporting Service base fee for this volume is $\$ 21.00$ per article (or portion thereof), which should be paid directly to the Copyright Clearance Center (CCC), 222 Rosewood Drive, Danvers, MA 01923 . Payment may also be made electronically through CCC Online at copyright.com. Other copying for republication, resale, advertising or promotion, or any form of systematic or multiple reproduction of any material in this book is prohibited except with permission in writing from the publisher. The CCC fee code is 0277$786 \mathrm{X} / 20 / \$ 21.00$.

Printed in the United States of America by Curran Associates, Inc., under license from SPIE.

Publication of record for individual papers is online in the SPIE Digital Library.

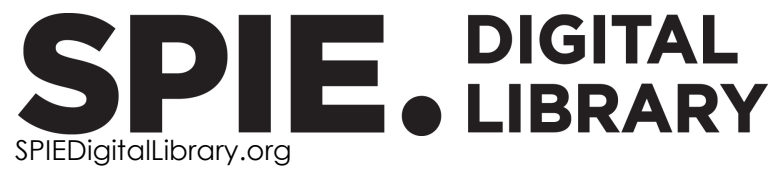

Paper Numbering: Proceedings of SPIE follow an e-First publication model. A unique citation identifier (CID) number is assigned to each article at the time of publication. Utilization of CIDs allows articles to be fully citable as soon as they are published online, and connects the same identifier to all online and print versions of the publication. SPIE uses a seven-digit CID article numbering system structured as follows:

- The first five digits correspond to the SPIE volume number.

- The last two digits indicate publication order within the volume using a Base 36 numbering system employing both numerals and letters. These two-number sets start with 00, 01, 02, 03, 04, $05,06,07,08,09,0 A, 0 B \ldots$ OZ, followed by 10-1Z, 20-2Z, etc. The CID Number appears on each page of the manuscript. 


\section{Contents}

MICRO AND NANO OPTICS

$1146703 \quad$ Natural in-plane hyperbolic crystals for far-infrared optical components [1 1467-2]

1146704 Optical computing with photonic CMOSFETs: A new way to look into process integration, circuit, and layout designs for next generation ULSI or mixed-signal ASICs [11467-3]

1146706 Amplitude and phase engineered all-dielectric metasurface for finite energy self-accelerating airy beam generation [11467-5]

1146707 Implementing of inverse designed power splitters by using effective medium theory [11467-6]

1146708 Identification of zirconia and hafnia crystalline phases by optical spectroscopy from firstprinciples [11467-7]

1146709 Photonic bandgap optimized by artificial bee colony algorithm [11467-8]

NANOMANUFACTURING OF ID AND 2D NANOMATERIALS FOR PHOTONICS APPLICATIONS

11467 OD Process repeatability in volume manufacturing of nanostructures utilizing nanoimprint lithography [11467-12]

DEVICES AND PROPERTIES OF NANOSTRUCTURES FOR PHOTONICS AND BIOMEDICAL APPLICATIONS

$114670 \mathrm{~J} \quad$ Simulation and modeling of fabricated metasurface optical device measured via polarimetric scatterometer [11467-18]

11467 OK Performance analysis of thin film CIGS solar cell at different values of thickness, bandgap and temperature through numerical simulation [11467-19]

LIGHT-MATTER INTERACTIONS IN ID AND 2D NANOMATERIALS

1146700 Spectroscopy using tunable liquid crystal Fourier filters [1 1467-23]

$11467 \mathrm{OQ} \quad$ Ultra-low landing energy scanning electron microscopy for nanoengineering applications and metrology (Invited Paper) [11467-25]

11467 OS Wavelength-tunable planar plasmonic absorber based on PCM's nanoresonators [11467-27] 
$114670 \mathrm{X} \quad$ Surface engineering of small and bright upconversion nanoparticles providing chemical and colloidal stability in biological media (Invited Paper) [1 1467-31]

11467 OY Visible upconversion photoluminescence of bulk silicon and mesoscale silicon nanoparticles [11467-32]

INNOVATIVE PATTERNING, MATERIALS ENGINEERING, NANOFABRICATION, AND NANOLITHOGRAPHY FOR PHOTONICS AND BIOMEDICAL APPLICATIONS

$114671 \mathrm{H} \quad$ Processing of organic electro-optic materials for commercial applications [1 1467-51]

$1146711 \quad$ Innovative patterning of electrospinning fabrication nano scaffolds with cell culturing for liver tissue engineering [11467-52]

$114671 \mathrm{~K} \quad$ Hybrid plasmonic substrates fabricated by a nanoline-gap-modulated assembly of nanoparticles [1 1467-54]

\section{NANOSTRUCTURED THIN FILMS AND DEVICES}

$1146710 \quad$ Birefringence analysis of photo-addressable azopolymer thin films from spatial frequency response of focused surface plasmon [11467-58]

11467 1R Characterization of C-Ti multilayer thin films obtained by TVA technology [11467-61]

$114671 \mathrm{U} \quad$ Magnetically tunable visible reflectivity utilizing the electron accumulation in indium-tin-oxide waveguide layer with subwavelength grating [1 1467-64]

$114671 \mathrm{~V} \quad$ Formation of all-silica sculptured thin films based optical elements on crystal substrates [1 1467-65]

\section{POSTER SESSION}

$114671 Y \quad$ Analysis of tilted subwavelength periodical waveguides: polarization effects [1 1467-68]

$1146712 \quad$ Properties of carbon nanoparticles for diagnostics of speckle fields [1 1467-69]

1146720 Investigation of stochastization of optical radiation scattered by polydisperse carbon nanoparticles [1 1467-70]

$1146721 \quad$ Synthesis of antibiotic-silver nanoparticles complexes, their properties, and application for investigation of antibiotic-resistance mechanisms [11467-71]

1146722 Thermal effects analysis in photonic crystal resonant cavities [1 1467-72] 
1146729 Waveguide crossing design using particle optimization algorithm [11467-79]

$114672 \mathrm{~A} \quad$ Narrowband plasmonic absorber with phase-change-material layer [1 1467-80]

$114672 \mathrm{H} \quad$ Ab-initio study of oxygen and carbon contamination on GaAs(100) planar and nanowire photocathode [11467-87]

$1146721 \quad$ Ultra-steep-slope transistor enabled by an atomic memristive switch [1 1467-88]

$114672 \mathrm{~J}$ Sensitivity optimization of an evanescent field particle detector based on a silicon nitride waveguide [11467-89]

$114672 \mathrm{~K} \quad$ Fast optical humidity sensor based on nanostructured hydrogels [1 1467-90] 
Proc. of SPIE Vol. 11467 1146701-6

Downloaded From: https://www.spiedigitallibrary.org/conference-proceedings-of-spie on 26 Apr 2023
Terms of Use: https://www.spiedigitallibrary.org/terms-of-use 